\title{
The Implementation Of Online-Based Project Based Learning During The Covid-19 Pandemic In Malay Arabic Courses Semester V In Indonesian Literatures Jambi University
}

\author{
Warni $^{1}$, Rengki Afria ${ }^{2}$ \\ ${ }^{1,3}$ Magister Pendidikan Bahasa, Pascasarjana, Universitas Jambi, Jambi, Indonesia \\ ${ }^{2 *}$ Sastra Indonesia, FKIP, Nama Universitas Jambi, Jambi, Indonesia \\ Email: ${ }^{1}$ warni@ @unja.ac.id ${ }^{2 *}$ rengkiafria@gmail.com \\ Informasi Artikel \\ Diterima : 11-12-2021 \\ Revisi : 16-12-2021 \\ Diterbitkan : 20-01-2022 \\ Keywords: \\ Implementation \\ Project Based Learning \\ Malay Arabic Letter \\ Learning

\begin{abstract}
This study aims to describe the implementation of online-based Project Based Learning in the Arabic-Malay Script Course in Semester V of the Indonesian Literature Study Program, FKIP, Jambi University. The method used is an action research method. Sources of data in the form of stimulus and student responses in learning. The results of the study concluded that the implementation of PJBL in the Malay Arabic Script course had been carried out well. This is evidenced by the students' awareness of the importance of the Malay Arabic script.
\end{abstract}

\section{INTRODUCTION}

Education is a conscious and planned effort to create a learning atmosphere and learning process so that students actively develop their potential to have religious spiritual strength, self-control, personality, intelligence, noble character, and skills needed by themselves and society (Government of the Republic of Indonesia, 2003). Education aims to form a broad-minded, quality, and virtuous human character in everyday life.

At the present time education functions as a benchmark in global competition, where educated resources are skilled in all matters relating to their ability to compete. and productive.

In Indonesia, education is divided into several levels according to the level of affective, cognitive, and psychomotor development of students. The level of education starts from early childhood education, basic education, secondary education, and higher education. Higher education is the last level in developing the quality of students' skills which include attitudes, values, critical and academic thinking, until they get degrees, diplomas, bachelor's, master's and doctoral degrees.

Jambi University is a state university located in Jambi province. In its development, around 2015-2021, Jambi University has made progress in the field of Tridharma; education, research, and service. This is evidenced by the quality of the resources of educators and students who are able to compete nationally, as well as globally. This statement is also supported by the increase in scientific publications and community service partners in Jambi province.

Jambi University has eight faculties and 88 study programs. The curriculum used at Jambi university is the 2013 curriculum based on the KKNI, but after the Merdeka Campus Program from the Ministry of Education and Culture, Jambi University began to improve the curriculum in accordance with the Merdeka Learning Campus Merdeka (MBKM) curriculum. ). One of the faculties at Jambi University is the Faculty of Teacher Training and Education (FKIP). From several departments at FKIP, there is the Department of History, Art, and Archeology. This department is a new department which was merged from the previous faculty into FKIP. There are four study programs under the scope of the Department of History, Art, and Archeology, namely History, Dramatic Arts, Dance and Music Indonesian Literature, and Archeology.

Indonesian Literature Study Program is a study program within the scope of the Department of History, Art, and Archeology, Faculty of Teacher Training and Education, Jambi University. Indonesian Literature 
Study Program basically examines the scientific fields of Indonesian and regional language and literature by emphasizing concepts, theories in learning. Compulsory courses related to expertise. One of the compulsory subjects in the Indonesian literature study program is Malay Arabic Script.

The Arabic-Malay Script (AAM) course is a compulsory subject of expertise in the Indonesian literature study program at Jambi University. is to search for, inventory, document, and study scientifically sources of texts written in Arabic-Malay script to explore historical and cultural potentials as well as local wisdom in Jambi province.

Learning Arabic-Malay script can be done with a learning model, one of which is a projectbased learning model. The use of this model in learning will allow students to be able to solve the problems that are obtained in the course. The Arabic-Malay Script (AAM) course was chosen as the object of study because the problems faced by students are that some of them already know, but have not been able to comprehensively read scripted texts. Arabic Malay. Thus, of course, there is a need for methods and approaches in learning so that students are able to overcome these problems with the guidance of a lecturer. In addition, the understanding, experience, and expertise that will be produced later can help complete the next course. Precisely with the existence of Merdeka Learning Campus Merdeka (MBKM), of course this Project Based Learning model is suitable to be applied with the output of increasing student learning abilities in solving problems independently, critically, and productively.

Project-Based Learning is a learning model that uses projects/activities as the core of learning. Students explore, assess, interpret, synthesize and produce various forms of learning outcomes. ProjectBased Learning is a learning model that uses problems as a step early in collecting and integrating new knowledge based on his experience in real activities. PjBL is an in-depth investigation of a real world topic. The steps for implementing project-based learning are determining basic questions, preparing project plans, compiling schedules, monitoring, testing results, and evaluating experiences (Kemendikbud, 2013).

Learning during the Covid-19 pandemic has made a big change in education in Indonesia. This change is an innovation that requires the academic community to master technology as a medium for giving lectures. During 2020, not only at the University of Jambi, but also all universities in Indonesia using the online method in the lecture process. However, it is possible that before the Covid-19 pandemic, Jambi universities and other universities had organized online learning by utilizing e-learning.

Educational innovation research by choosing project based learning as a learning method that will be developed by lecturers at the Jambi University based online in the teaching and learning process is considered very appropriate. In general, this of course can create human resources (students) who are independent, mastering technology, competitive, creative, productive, and others in facing global challenges. In addition, through project-based learning, students will get used to thinking critically, liking challenges, being innovative, so that alumni are able to compete in all fields in the world of work. In particular, project-based learning as a reflection and evaluation of lecturers provides learning. These reflections and evaluations are used as notes for improvement, both in materials, methods, and learning outputs in the future. Project-based learning has the potential to train to increase student learning activities and motivation. The project-based learning model allows students to design a problem and find a solution on their own (Kristanti et al., 2016).

To improve students' ability to solve problems and find knowledge and skills in learning, the Project Based Learning method is the right method in implementing learning during the COVID-19 pandemic.

Research on Project based learning has been done by many previous researchers. This indicates that Project based learning is an effective learning model applied in the teaching and learning process. Previous studies related to this research are also relevant research that is used as a benchmark for similarities and differences.

Sari (2018) investigated the effect of problem-based learning and project-based learning on the achievement motivation. (2) Project based learning has an effect on achievement motivation of fifth grade elementary school students; and (3) Problem based learning and Project based learning have different effects on achievement motivation in fifth grade elementary school students. Furthermore, Kusadi et al., (2020) researched the Project Based Learning Model for Social Skills and Creative Thinking. The research results are; (1) there is a simultaneous effect of project-based learning models on students' social 
skills and creative thinking skills, (2) there is an effect of project-based learning models on students' social skills, (3) there is an effect of project-based learning models on students' creative thinking skills. In the project-based learning model, it displays all important intellectual and social dispositions needed to solve real-world problems. By being able to master and apply this learning model, it is hoped that prospective educators and educators have the ability to design and organize good learning, so that they can realize optimal learning. for students and satisfaction for teachers.

Susilawati et al., (2017) researched on The Application of Project-Based Learning Using Mind Maps to Improve Students' Environmental Attitudes towards Waste Management in Junior High Schools. Based on the findings, it was concluded that the implementation of a learning model-based project with a waste-themed mind map and its management was able to improve students' environmental attitudes which were better than learning activities without a mind map. Furthermore, the application was effective in increasing students' environmental care attitudes towards waste and its management. provides several implications for science teachers to apply learning models to not only increase students' knowledge but also awareness of environmental issues.

Furthermore, Yamin et al., (2020) researched about Project based learning to enhance creative thinking skills of the non-science students. Based on the analysis of the research results, it can be concluded that meaningful science learning will help students develop creative thinking skills. Projectbased integrated science learning with the theme of water pollution can increase students' creative thinking skills by $89 \%$ (very good category). The achievement of peer assessment indicators is $87 \%$, while the achievement of creativity indicator products is $88 \%$. Thus, project-based science learning can be an alternative to increase the creativity of students' thinking skills of non-science students.

Meanwhile, Almulla (2020) researched "The Effectiveness of the Project-Based Learning (PBL) Approach as a Way to Engage Students in Learning". Therefore, future work should consider establishing guidelines for teachers to incorporate PBL approaches in various areas of learning and learning processes. Future efforts should also reflect the opinions of teachers and other higher education stakeholders regarding PBL approaches for use in academic settings. It is recommended to explore the constraints and facilitate action in future work, bearing in mind that different points of view from different regions and cultures of the world will undoubtedly enhance research. Future work may also provide more insight into how to deal with learning problems in universities in different educational settings.

Yustina et al., (2020) researched the effects of blended learning and project-based learning on pre-service biology teachers' creative thinking skills through online learning in the COVID-19 pandemic. The results of the study found that the average creative thinking score of experimental class students was 91 with an $\mathrm{N}$-gain index of 0.62 higher (very creative) compared to the control class (76) with an $\mathrm{N}$-gain index of 0.51 (quite creative). Blended Learning and Project Based Learning are quite influential in improving the creative thinking skills of pre-service teachers, BL and $\mathrm{Pj}$-BL are quite more effective than conventional learning in improving the creative thinking of pre-service teachers in biology learning (innovation of biology learning courses) in the fifth semester of the biology education study program because students and lecturers have previous online learning experience. Then it is also supported by the existence of internet network equipment facilities on campus that can be used by pre-service teachers and lecturers as well as pre-service teachers who have received training in the previous semester, namely online learning in virtual learning media. The implications of this research can contribute to how to implement an effective learning process using BL and this can be considered by policy makers for future implementation of learning systems that can be applied by Blended Learning (BL) and Project Based Learning.

Lastly, Hadiyanto et al., (2021) researched on The Effective Use of Full Online Learning to Replace Classroom Learning During the Covid-19 Pandemic Due to the start of the Covid-19 pandemic. The results of the study concluded that the use of online learning related to general implementation, course communication, resource authenticity, and time management, especially for technical skills, had not been implemented optimally at the faculty level in Higher Education. Therefore, lecturers need to pay attention, implement, and evaluate the indicators needed to achieve online teaching and learning objectives. Furthermore, policy makers need to consider various solutions and steps as future projections. Obstacles, solutions, and projections of courageous learning for prospective teachers are important to study because the online learning system is currently being carried out by lecturers at institutions due to the outbreak of Covid-19. 
From this relevant study, there are similarities and differences with this study. The equation lies in the use of models and approaches used in the learning process. While the difference lies in the method in carrying out the research. This research focuses on classroom action research that is applied in the online Malay Arabic Script course. Thus, the results of the analysis, findings, discussion and implications obtained will also differ from the relevant research so that new conclusions can be obtained in implementing the project based learning model with the action method.

\section{METHOD}

This research is a qualitative descriptive research. Literally, a qualitative descriptive method is a method that seeks to explain phenomena that are carried out according to the facts obtained in the classroom. This research presentation explains the learning conditions as they are without adding or reducing the analysis of the results obtained. The method used in this research is action research method. Action research aims to reveal the causes of the problem and provide steps to solve the problem.

Action research method is a research method used to test, develop. Finding and creating new actions, so that if these actions are applied to work, the work implementation process will be easier, faster, and the results are more numerous and of high quality (Sugiono, 2015).

Action research is inseparable from two main things, namely improvement and involvement. It can refer to the objectives of action research, namely: (a) improving practice; (b) professional development in the sense of increasing practitioners' understanding of the capabilities of the practice; (c) improve the circumstances or situations in which the practice is carried out.

This research was conducted at the Indonesian Literature Study Program, Department of History, Art, and Archeology, FKIP, Jambi University. The time of the research is carried out in the odd semester of 2021-2022. The participants in this study were students of Indonesian literature in the third semester of odd and even classes as many as 38 students.

The data collection methods used in this study were interviews and tests. Interviews were conducted to obtain direct data in terms of reading and writing skills in Arabic-Malay script. The interview technique used was unstructured interview technique. While the test method was used to measure writing and reading skills. Malay Arabic script before and after learning is applied. The test was carried out in two stages in each cycle, namely pre-test and post-test. The pre-test was conducted to determine the initial ability to understand the material to be studied, while the post-test was carried out at the end after the implementation of the learning action.

The data analysis method in this study used a qualitative descriptive analysis method. An indicator of success in classroom action research is an increase in writing and reading skills in the Malay Arabic script.

\section{RESULT AND DISCUSSION}

Research on learning innovation with the title Implementation of online-based Project Based Learning on the Malay Arabic Script Course Semester III Indonesian Literature Study Program, FKIP, Jambi University has been carried out. In this case, students of Indonesian Literature Semester III are used as learning respondents. There are 40 students consisting of 2 classes. The following is a list of names of students who are members of the implementation of learning innovations.

Because it is still during the Covid-19 Pandemic and the Chancellor's regulation to conduct online-based lectures, the implementation of this learning is carried out using online methods and zoom meetings as the media used.

Based on the results of the pretest using the source of the questionnaire survey conducted in cycle 1: (https://docs.google.com/forms/d/1sDBlVsV2fCyBUR8o0ECFA-RfLvleSEZerLKHHf8lcfs/edit) by using basic questions to determine students' basic understanding of the Malay Arabic script. The survey results

found

that:

Table1

Result Preetest Question

\begin{tabular}{ll}
\hline Question & Have you ever heard of Malay Arabic Script (Pegon) before? \\
Survey 1 & \\
\hline
\end{tabular}




\begin{tabular}{lllll}
\hline (no 1) & never & $\begin{array}{l}\text { Absolutely } \\
\text { never }\end{array}$ & doubt \\
\hline Indicator & ever & 9 & 2 & 5 \\
\hline $\begin{array}{l}\text { Amount of } \\
\text { Participants }\end{array}$ & 17 & $23,7 \%$ & $6,1 \%$ & $15,2 \%$ \\
\hline Percentage & $51,5 \%$ & & & \\
\hline
\end{tabular}

From the results of a questionnaire about the frequency of students' introduction to the Malay Arabic script, it was found that out of 40 students only 33 respondents answered the question. The percentage results can be concluded that most students are familiar with the Malay Arabic script with the acquisition of $51.5 \%$ or 17 students from 33 respondents.

Table 2

Result Pretest Questions

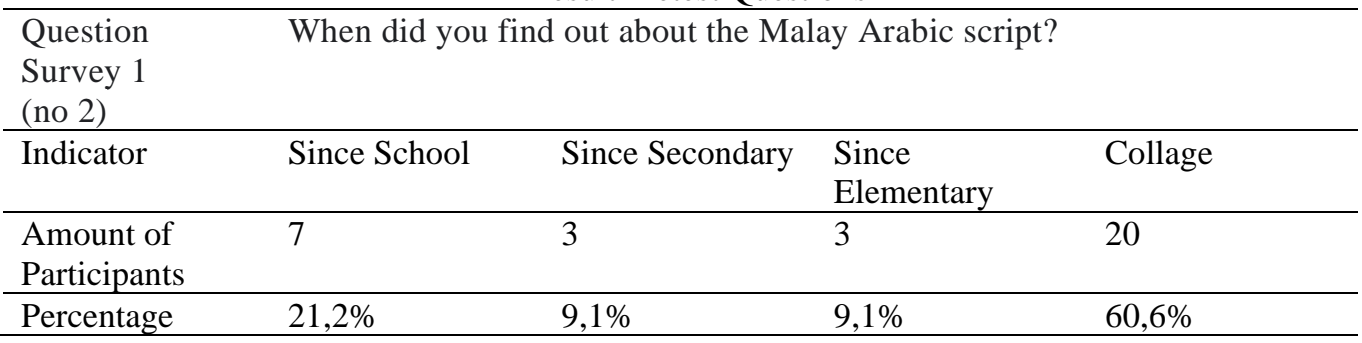

The results of the questionnaire on student experiences in knowing the existence of Malay Arabic script were found that 33 respondents answered from 40 students. These results were obtained as a basis for knowing students' knowledge in recognizing Malay Arabic script so that learning could be adjusted accordingly.

Can you spell and read Malay Arabic Script?

Based on the questionnaire, it was found that students who could spell and read Arabic-Malay script were 12 people or $36.4 \%$, could not be as many as 6 people or $18.2 \%$, maybe as many as 2 people or $6.1 \%$, and a little could be as many as 13 . people or $39.4 \%$. This is a good result in planning and maturation of the material in the learning process later.

Can you write Malay Arabic script?

From this questionnaire, it was found that 13 students who could write Arabic-Malay script or $39.4 \%, 17$ students or $51.5 \%$, and 3 people or $9.1 \%$ could not. The results of this questionnaire can be concluded that the initial ability of students in writing Arabic-Malay script can be categorized as good, because only a few people cannot read. This is of course influenced by several factors, such as the lack of experience and knowledge of some students in the Malay Arabic script.

Is learning the Malay Arabic script important?

From the results obtained in this questionnaire, the urgency of learning Arabic Malay script is yes, it is important to get 20 students or $60.6 \%$, not important is 0 or $0 \%$, maybe 8 people are important or $24.2 \%$, and very important is 5 students or $15.2 \%$. This result is also categorized as good, because the students' views in learning Arabic-Malay script get a positive response.

As it is known that the Malay Arabic script is one of the scripts whose existence must be maintained continuously, given that the patterns, systems, history, and other past information are written in Malay Arabic scripts. So, to express this, reading skills are needed.

Do you have a desire to be able to master the Malay Arabic script? 
The results of this questionnaire were obtained by 28 people who answered yes. In mastering the Malay Arabic script, not as many as 0, maybe as many as 1 person or 3.0\%, as few as 4 people or $12.1 \%$. The ability to read Malay Arabic script makes it easier for students to find linguistic, literary, historical, and other cultural data contained in Arabic Malay scripts and scripts.

Is Malay Arabic Script difficult to learn?

The results of this questionnaire show that the level of difficulty in learning and identifying Malay Arabic script is high considering that the absorption of hijayah letters into Malay and also no punctuation marks, writing errors, and many other things become obstacles. This is in accordance with the results of the questionnaire obtained such as very difficult there are 2 people or $6.3 \%$, easy 12 people, difficult 15 people, very easy 1 person, not too 1 person, and not too easy and not too difficult 1 person.

What are your difficulties in learning the Malay Arabic Script?

From this questionnaire, various data were obtained about difficulties in learning the Malay Arabic script, such as how to spell and read, and write. Therefore, it is necessary to mature the concepts, materials and methods used in the learning process so that students are able to identify, recognize, read, write, and analyze Arabic-Malay scripts and texts.

Should the Malay Arabic script be preserved?? 100\% yes

From the results of the questionnaire, it can be seen that all respondents agree that the Malay Arabic script needs to be preserved, given that the unidentified manuscripts scattered in Jambi province are in Arabic-Malay script. It aims to reveal the sources of local wisdom in the past that are inherited at this time.

What do you think about Malay Arabic script?

The results of this questionnaire concluded that the students' opinion of the Malay Arabic script was very good. It is evident from the results of student questionnaires such as:

"I think the Arabic-Malay script is very interesting and unique, namely in the form of words that we usually call but use Arabic letters. The Arabic-Malay script itself comes from the Arabic script. Its appearance was based on the Arabs who entered Indonesia or the archipelago, in my opinion, the MalayArabic script was difficult easy because it relates to Arabic letters and words that we usually use only in the form of Malay or Arabic script. Personally I really want to be able to read, write and understand the Saudi Arabic script without having to look at the letters many times when I want to write. And by learning the Malay Arabic script, we can increase our knowledge and abilities as well as our expertise and our insight can increase. "

Implementation Results

The implementation of project-based learning is carried out in various steps, such as:

a. At the start of learning, the lecturer explains the competencies to be achieved at the end of the lesson

b. Lecturer explains learning material

c. The lecturer divides the students into several groups, 1 group consists of 3 to 5 students. Each group is led by one smart student to be the tutor

d. The lecturer gives practice questions to each group to work on together

e. During group assignments, students who are appointed as tutors provide guidance to other students who are having difficulties.

f. Lecturer collects answers to practice questions

g. The lecturer evaluates by comparing the answers from student work with the correct answers

h. Lecturers give awards to groups that have worked well together

i. During group work, students who are appointed as Mentors provide guidance to other students who are experiencing difficulties.

j. Lecturer collects answers to practice questions

$\mathrm{k}$. The lecturer evaluates by comparing the answers from the student's homework with the correct answers

1. Lecturers give awards to outstanding teams

The Malay Arabic Script course is a theoretical and practical course which of course the output obtained is the students' understanding of reading and writing the Malay Arabic Script. The contribution of this course will be used as knowledge and experience in following the Philology course. In the study of 
philology, students are expected to be able to examine texts that contain elements of literature, culture, and history.

With the experience and knowledge gained by students in the Malay Arabic Script course, it is easier for students to understand, transliterate, criticize, and study texts. This is because the text that is taken as the object of study is not only a Latin script, but also a Malay Arabic script. Bearing in mind that most of the texts containing information about culture, literature, language, and history in Jambi Province are using the Malay Arabic script.

\section{CONCLUSSION}

The results of the analysis obtained in this study concluded that the implementation of online-based Project Based Learning in the Arabic-Malay Script Course in Semester V of the Indonesian Literature Study Program, FKIP, Jambi University had been carried out well. Students are able to identify, write, read, and analyze Arabic-Malay script.

\section{REFERENCES}

[1] Afandi, M., Chamalah, E., \& Wardani, O. P. (2013). Model dan Metode Pembelajaran di Sekolah. In Perpustakaan Nasional Katalog Dalam Terbitan (KDT) (Vol. 392, Issue 2). https://doi.org/10.1007/s00423-006-0143-4

[2] Almulla, M. A. (2020). The Effectiveness of the Project-Based Learning (PBL) Approach as a Way to Engage Students in Learning. SAGE Open, 10(3), 215824402093870. https://doi.org/10.1177/2158244020938702

[3] Aqib, Z. (2013). Model-Model, Media dan Strategi Pembelajaran Kontekstual (inovatif). Bandung: CV Yrama Widya.

[4] Hadiyanto, Wulandari, S., Wilyanti, L. S., Supian, Afria, R., \& Nazarudin. (2021). The Effective Use of Full Online Learning to Replace Classroom Learning During the Covid-19 Pandemic. International Journal of Current Research and Review, 23-32. https://doi.org/10.31782/IJCRR.2021.SP205

[5] Kemendikbud. (2013). Permedikbud Nomor 65 Tahun 2013 Tentang Standar Proses. Jakarta: Kemdikbud.

[6] Kristanti, Y., Subiki, S., \& Handayani, R. (2016). Model Pembelajaran Berbasis Proyek (Project Based Learning Model) Pada Pempelajaran Fisika di SMA. Jurnal Pembelajaran Fisika, 5(2), 122-128. https://jurnal.unej.ac.id/index.php/JPF/article/view/3958

[7] Kusadi, N. M. R., Sriartha, I. P., \& Kertih, I. W. (2020). Model Pembelajaran Project Based Learning Terhadap Keterampilan Sosial dan Berpikir Kreatif. Thinking Skills and Creativity Journal, 3(1), 18-27. https://doi.org/http://dx.doi.org/10.23887/tscj.v3i1.24661

[8] O'Brien. R. (2001). An overview of the Methodological Approach of Action Research. Toronto: Faculty of Information Studies.

[9] Pemerintah Republik Indonesia. (2003). Undang-Undang Republik Indonesia Nomor 20 Tahun 2003 Sistem Pendidikan Nasional. Lembaran Negara Republik Indonesia Tahun 2003 Nomor 4301: Jakarta.

[10] Sari, I. K. (2018). The effect of problem-based learning and project-based learning on the achievement motivation. Jurnal Prima Edukasia, 6(2), 129-135. https://doi.org/10.21831/jpe.v6i2.17956

[11] Sugiono. (2015). Metode Penelitian Tindakan (Action Research). Prosiding Seminar Nasional Jurusan PGSD FIP UNP, 1(2015), 1-120. http://ejournal.unp.ac.id/index.php/prosidingpgsd/article/view/4846

[12] Susilawati, A., Hernani, H., \& Sinaga, P. (2017). The Application of Project-Based Learning Using Mind Maps to Improve Students' Environmental Attitudes towards Waste Management in Junior High Schools. International Journal of Education, 9(2), 120-125. https://doi.org/10.17509/ije.v9i2.5466

[13] Yamin, Y., Permanasari, A., Redjeki, S., \& Sopandi, W. (2020). Project Based Learning to Enhance Creative Thinking Skills of the Non-Science Students. JHSS (JOURNAL OF HUMANITIES AND SOCIAL STUDIES), 4(2), 107-111. https://doi.org/10.33751/jhss.v4i2.2450

[14] Yustina, Syafii, W., \& Vebrianto, R. (2020). The effects of blended learning and project-based learning on pre-service biology teachers' creative thinking skills through online learning in the COVID-19 pandemic. Jurnal Pendidikan IPA Indonesia, 9(3), 408-420. https://doi.org/10.15294/jpii.v9i3.24706 